\title{
Suscetibilidade de Aspergillus spp. a Ácidos Orgânicos Conforme o pH
}

María de Jesús Alcano (I), Raquel Carine Jahn (I), Cátia Daiane Scherer (I), Évelin Francine Wigmann (I), Fernanda Saccomori (I), Vivian Machado Moraes (I), Marcelo Valle Garcia (I), Marina Venturini Copetti (I)

(I) UFSM - Universidade Federal de Santa Maria (Av Roraima 1000, CCR/DTCA, Prédio 42, sala 3210. CEP 97104-900, Santa Maria-RS )

\section{Resumo}

O gênero Aspergillus possui ampla importância na microbiologia alimentar, seja como produtor de metabólitos úteis (ex. ácido cítrico e amilases) ou como deteriorantes e produtores de metabólitos tóxicos (ex. aflatoxinas e ocratoxinas). Tradicionalmente têm sido utilizados diversos conservantes com vistas à prevenção da deterioração de alimentos, porém existe uma crescente demanda dos consumidores por alimentos isentos de substâncias antimicrobianas sintetizadas quimicamente, restando poucas alternativas para controlar este problema. Em função do status de muitos dos ácidos orgânicos de GRAS (Geralmente Reconhecido como Seguro), o uso destes como conservantes em alimentos e matérias primas para humanos e animais tem se destacado. Diante disto, o objetivo desta pesquisa foi de avaliar a suscetibilidade de isolados de Aspergillus section Nigri (A. carbonarius, A. luchuensis, A. niger e A. tubingensis) e section Flavi (A. flavus e A. parasiticus) aos ácidos orgânicos sórbico e acético em diferentes valores de $\mathrm{pH}$. Foi utilizado um arranjo fatorial com 9 fungos, 4 níveis de $\mathrm{pH}(4,5 ; 5,0 ; 5,5 ;$ e 6,0$)$ e 2 tipos de ácidos nas concentrações: Ácido sórbico $(0 ; 0,5 ; 1 ; 2 ; 4 ; 8 ; 16 ; 32 \mathrm{mM})$ e ácido acético $(12,5 ; 25 ; 50$; 100; 200; 400 e $800 \mathrm{mM})$. Os experimentos foram conduzidos em triplicata, incubados por 6 dias e avaliadas as concentrações inibitórias baseando-se numa escala dicotômica; cresceu e não cresceu. Ambos os

\footnotetext{
Referência:

María de Jesús Alcano, Raquel Carine Jahn, Cátia Daiane Scherer, Évelin Francine Wigmann, Fernanda Saccomori, Vivian Machado Moraes, Marcelo Valle Garcia, Marina Venturini Copetti. Suscetibilidade de Aspergillus spp. a Ácidos Orgânicos Conforme o pH. In: Anais do 12 Congresso Latinoamericano de Microbiologia e Higiene de Alimentos - MICROAL 2014 [= Blucher Food Science Proceedings, num.1, vol.1]. São Paulo: Editora Blucher, 2014. 
ácidos testados apresentaram maior eficiência quanto menor o $\mathrm{pH}$ testado, sendo que para ácido acético a cada aumento de 0,5 no $\mathrm{pH}$, dobrava a dose necessária para a ação antifúngica, independente da espécie avaliada. $\mathrm{O}$ ácido que apresentou maior poder antifúngico foi o ácido sórbico, visto que são necessárias concentrações mais baixas para encontrar o mesmo efeito, quando comparado com o ácido acético. Houve diferença quanto à sensibilidade das espécies testadas para ambos os ácidos avaliados. A. carbonarius e A. flavus foram 2 vezes mais sensíveis ao ácido acético quando comparado com os demais isolados. Já para ácido sórbico as espécies mais sensíveis foram A. flavus e A. parasiticus, e as mais resistentes A. niger e A. tubingensis. Demonstra-se assim a importância de se considerar tanto o $\mathrm{pH}$ quanto as espécies fúngicas predominantes no produto ao se calcular a dose do ácido sórbico para garantir a estabilidade dos alimentos frente a deterioração fúngica.

Palavras-Chave: concentração inibitória, ácido acético, ácido sórbico, conservantes

Agência de Fomento: CNPq, FAPERGS (Bolsas de Iniciação Científica) e Fundayacucho (Bolsa de Mestrado) 